\title{
EFFECT OF MATURITY STAGE ON PHYSICAL AND CHEMICAL CHARACTERISTICS AND DETERMINATION OF HARVEST TIME OF SUGAR SNAP PEA PODS \\ El-Seifi ${ }^{\star}$,S.K.; M.A. Hassan*;R. E. I. El-Bassiouny ${ }^{\star \star} ; M . W . M$. Elwan ${ }^{\star}$ and I.N.Nasef* \\ * Department of Horticulture, Faculty of Agriculture, Suez Canal University, Ismailia, Egypt. \\ ${ }^{* *}$ Vegetable Handling Department, Horticulture Research Institute, Agriculture Research Center, Giza, Egypt.
}

\begin{abstract}
Two field experiments were carried out at the experimental station of the Faculty of Agriculture, Suez Canal University, Ismailia, Egypt during the winter seasons of 2009-2010 and 2010-2011. The study aimed to investigate the effect ofmaturity stage on the nutritional quality and determination of the best maturity stage of sugar snap peassuitable for harvesting. Results showed that fresh weight of pods was increasedand then decreased.Length and width increased until 48, 32 days after flowering (DAF), respectively, and then decreased. Dry matter and crude fiber increased while chlorophyll and vitamin $C$ decreased during pod development. Sugar content and SSC increased and then decreased while phenolic content decreased, and then increased with maturation of pod. The obtained results showed that the best maturity stage is at $28 \mathrm{DAF}$.
\end{abstract}

Keywords: sugar snap peas, maturity stage, harvest, Ascorbic acid, fiber, total sugar, quality.

\section{INTRODUCTION}

Sugar snap pea(Pisumsativum L. var.saccharatum)is newer typeof peas. The modern sugar snap pea is the progeny of a cross between snow peas(Pisumsativum L. var. macrocarpon) and an unusual pea that was tightly podded with thick walls. The result is a pea that breaks or snaps like a green bean; the pods have thick walls, are sweet, and are edible (except for the strings). The sugar snap pea is allowed to mature and become fully rounded. The sugar snap pea has well developed seeds and is picked more mature and is fully rounded. Sugar snap peas should be harvested after they have developed seeds, similar to garden peas.Sugar snap pea differ from the traditional garden peas, as they have less fiber in the pods and it is eaten as whole tender pods without shelling. it may be eaten raw, lightly boiled, steamed or used in 'stir-frys'. It is known as edible podded peas because it does not have the same cross fiber in the wall of the pod as the common garden pea and can be eaten whole. Itis sowing for export as a vegetables, as well as, it plays an important role for human nutrition as a cheap source of protein, carbohydrates, vitamins, minerals and other nutrients.

To retain the best quality, edible-podded peas are harvested before physiological maturity is reached(Basterrechea and Hicks, 1991). Shortly after harvest, loss of sweetness and crispness, as well as degreening and the development of mealiness, may degrade the quality.Maturity at harvest is the 
most important factor that determines postharvest-life and final quality i.e.; appearance, texture, flavor, nutritive value of fruit-vegetables. For immature vegetables such as sugar snap peas, the optimum eating quality is reached before full maturity and delaying harvesting results in lower quality at harvest and faster deterioration rate after harvest. Harvesting at the proper stage of maturity is essential for optimum quality and often for the maintenance of this quality after harvest. No information is available in the literature about the change in nutritional quality during the growth cycle and proper harvest stage of sugar snap peas. Accordingly, the objectives of this study are to provide information on the effect of harvest time on the nutritional quality and determination of the best maturity stage of sugar snap peas suitable for harvesting.

\section{MATERIALS AND METHODS}

Two field experiments were carried out at the Experimental Research Farm, Faculty of Agriculture, Suez Canal University, Ismailia Governorate, Egypt, during the two successive winter seasons of 2009-2010 and 20102011 (from October 11, 2009 to March 14, 2010 and repeated on October 2, 2010 to March 5, 2011) to investigate the effects ofmaturity stage on the nutritional quality and determination of the best maturity stage of sugar snap peas (Pisumsativum L. var. saccharatum) cv. 'Super sugar snap' suitable for harvesting. Seeds were sown on October 11, 2009 and on October 2, 2010 for the two seasons, respectively. Seeds of sugar snap peas were sown at 10 $\mathrm{cm}$ within row and $1.00 \mathrm{~m}$ between rows, under drip irrigation system and the recommended cultural practices were followed.Soil texture was sandy (85.21\% sand, $3.29 \%$ clay and $11.5 \%$ silt), pH was 8.27 , EC was $0.47 \mathrm{dSm}-1$, Ca was 0.8 meq- 1 , Mg was 0.6 meq- 1 , $\mathrm{K}$ was 0.3 meq- 1 , Na was 3.0 meq- 1 , $\mathrm{HCO} 3$ was 1.6 meq- $1, \mathrm{Cl}$ was 3.0 meq- 1 and $\mathrm{SO} 4$ was 0.1 meq-1.To obtain samples of pods of uniform maturity, blossoms were labeled with coloured tags. The dates of tagging were December 20, 2009 and December 9, 2010. Hand-harvesting of pods commenced 8 days after labeling and serial sampling was done at 4 days intervals. Final sampling was taken at 52 days after labeling. Samples were collected in the morning between 7:30 and 8:00AM.

Recorded data:The following physical and chemical parameters were determined during pod development:

1. Physical parameters: Twenty one pods were harvested and divided into three replicates each one contains 7 pods then average weight, length and width of the pods were measured.

\section{Chemical parameters}

2.1. Total Chlorophyll and carotenoid contents: Total chlorophylls and carotenoids were determined,spectrophotometricaly,using acetone as a solvent, according to Lichenthaler and Wellburn (1983), and then calculated as $\mathrm{mg} / 100 \mathrm{~g}$ fresh weight.

2.2. Titratable acidity \%:Acidity was determined as citric acid according to Pearson (1970). 
2.3. Soluble solids content (SSC): Soluble solids content was determined by hand rafractometer according to A.O.A.C. (1996) expressed as ${ }^{\circ}$ Brix at 20 ${ }^{\circ} \mathrm{C}$.

2.4. Crude fiber \%: Crude fiber was determined as percentage according to Maynard (1970).

2.5. Dry matter:The percentage of dry matter content was determined by drying fresh pods in an oven at $70^{\circ} \mathrm{C}$ until constant weight was obtained. The results were calculated as percentage of fresh weight.

2.6. Ascorbic acid was determined by the titration method using 2,6dichlorophenolindophenol according to Pearson (1970).

2.7. Sugars content:

a) Total sugars were measured with phenol-sulfuric acid reagents spectrophotometrically at $480 \mathrm{~nm}$ according to Duboiset al.,(1956).

b) Reducing sugars were measured with alkaline copper and arsenomolybdate reagents spectrophotometrically at $540 \mathrm{~nm}$ according to Moore (1974).

c) Non reducing sugars were determined by the difference between total sugar and corresponding reducing sugar value. Glucose was used as standard for sugar estimation.

2.8. Total phenolic content: Total phenolic determination was carried out for pods according to Mazumdar and Majumder (2003).

Statistical analysis:Data were organized in a completely randomized block design (CRBD) with simple design, with three replications, in which each replicate was considered as a block. Experimental data were statistically analyzed using Co-Stat version 6.303 1998-2004 CoHort software 798 Lighthouse Ave PMP 320, Monterey, CA, 93940, USA. Analysis of variance (ANOVA) was performed to compare results. Least significance difference (LSD) test was used to compare means at the $5 \%$ significance level.

\section{RESULTS AND DISCUSSION}

Physical parameters:Results of the influence of maturity stage on average weight, length and width of pods were recorded in table (1). Rapid increase in average fresh weight, length and width ofpods occurred during early growth from 8 to 12 days after flowering (DAF). Fresh weight, after this stage, was increased continually until $44 \mathrm{DAF}$ and then it was gradually decrease, in the first season while it was increased until $48 \mathrm{DAF}$, then decreased, in the second season. The early increase in fresh weight of the pods was almost entirely due to the growth of pods which reached their maximum weight then decreased due to losing moisture during ripening. The obtained results are in harmony with the results of Bisson and Jones (1932) on garden peas and Watadal and Morris (1967) on snap bean.

Length of pods rapidly was increased from 8 to 12 DAF then increased gradually from 16 to $48 \mathrm{DAF}$, in both season. Data also indicated that changes in length of pods were limited during the period 24 to $44 \mathrm{DAF}$, in the second season. Maximum length was reached after 48 DAF. This 
increase may be due essentially to enlargement of the fleshy endocarpas reported before byWatadal and Morris (1967) on snap bean. The suitable harvest time for snap peas was reported to be when length of pods ranged from 6.4 to $7.6 \mathrm{~cm}$ (Hocking 1997). Width of pods was quickly increased from 8 to $12 \mathrm{DAF}$ then increased gradually from 16 to $32 \mathrm{DAF}$ then decreased until 52 DAF. Maximum width of pods was reached after 24 DAF, in the first season and after $28 \mathrm{DAF}$, in the second season.

Table (1): Average of weight, length and width of pod at different maturity stages during $2009-2010$ and $2010-2011$ seasons.

\begin{tabular}{l|ccc|ccc}
\hline $\mathbf{H}^{*}$. Date (days) & \multicolumn{3}{|c|}{$\mathbf{2 0 0 9 - 2 0 1 0}$} & \multicolumn{3}{c|}{$\mathbf{2 0 1 0 - 2 0 1 1}$} \\
\cline { 2 - 7 } & $\begin{array}{c}\text { Weight } \\
\text { (g/pod) }\end{array}$ & $\begin{array}{c}\text { Length } \\
\text { (cm) }\end{array}$ & $\begin{array}{c}\text { Width } \\
\text { (cm) }\end{array}$ & $\begin{array}{c}\text { Weight } \\
\text { (g/pod) }\end{array}$ & $\begin{array}{c}\text { Length } \\
\text { (cm) }\end{array}$ & $\begin{array}{c}\text { Width } \\
\text { (cm) }\end{array}$ \\
\hline $\mathbf{8}$ & $0.64 \mathrm{i}$ & $3.70 \mathrm{~h}$ & $0.80 \mathrm{f}$ & $0.53 \mathrm{j}$ & $3.60 \mathrm{~g}$ & $0.80 \mathrm{e}$ \\
$\mathbf{1 2}$ & $2.04 \mathrm{~h}$ & $5.77 \mathrm{~g}$ & $1.27 \mathrm{e}$ & $1.44 \mathrm{i}$ & $5.23 \mathrm{f}$ & $1.17 \mathrm{~d}$ \\
$\mathbf{1 6}$ & $2.87 \mathrm{~g}$ & $6.47 \mathrm{f}$ & $1.43 \mathrm{~d}$ & $2.27 \mathrm{~h}$ & $6.20 \mathrm{e}$ & $1.40 \mathrm{c}$ \\
$\mathbf{2 0}$ & $4.62 \mathrm{f}$ & $7.30 \mathrm{de}$ & $1.60 \mathrm{c}$ & $3.20 \mathrm{~g}$ & $6.53 \mathrm{~d}$ & $1.57 \mathrm{~b}$ \\
$\mathbf{2 4}$ & $6.53 \mathrm{e}$ & $7.40 \mathrm{c}-\mathrm{e}$ & $1.77 \mathrm{a}$ & $4.67 \mathrm{f}$ & $6.87 \mathrm{c}$ & $1.67 \mathrm{ab}$ \\
$\mathbf{2 8}$ & $7.43 \mathrm{~d}$ & $7.27 \mathrm{e}$ & $1.70 \mathrm{ab}$ & $5.92 \mathrm{e}$ & $7.27 \mathrm{~b}$ & $1.70 \mathrm{a}$ \\
$\mathbf{3 2}$ & $7.66 \mathrm{~cd}$ & $7.53 \mathrm{bc}$ & $1.77 \mathrm{a}$ & $6.07 \mathrm{de}$ & $7.07 \mathrm{bc}$ & $1.70 \mathrm{a}$ \\
$\mathbf{3 6}$ & $8.05 \mathrm{c}$ & $7.50 \mathrm{~b}-\mathbf{d}$ & $1.67 \mathrm{bc}$ & $6.59 \mathrm{~d}$ & $6.97 \mathrm{bc}$ & $1.63 \mathrm{ab}$ \\
$\mathbf{4 0}$ & $9.29 \mathrm{ab}$ & $7.6 \mathrm{a}-\mathrm{c}$ & $1.70 \mathrm{ab}$ & $8.24 \mathrm{c}$ & $7.20 \mathrm{~b}$ & $1.57 \mathrm{~b}$ \\
$\mathbf{4 4}$ & $9.74 \mathrm{a}$ & $7.57 \mathrm{bc}$ & $1.67 \mathrm{bc}$ & $8.49 \mathrm{bc}$ & $7.23 \mathrm{~b}$ & $1.60 \mathrm{ab}$ \\
$\mathbf{4 8}$ & $9.65 \mathrm{a}$ & $7.80 \mathrm{a}$ & $1.63 \mathrm{bc}$ & $9.50 \mathrm{a}$ & $7.90 \mathrm{a}$ & $1.57 \mathrm{~b}$ \\
$\mathbf{5 2}$ & $8.90 \mathrm{~b}$ & $7.70 \mathrm{ab}$ & $1.63 \mathrm{bc}$ & $8.85 \mathrm{~b}$ & $7.73 \mathrm{a}$ & $1.63 \mathrm{ab}$ \\
\hline
\end{tabular}

Values are the means of 3 replicates each with 7 pods. Values followed by the same letter within a column are not significantly different at the $0.05 \%$ level of probability according to LSD test. $\quad \mathbf{H}^{*}=$ Harvesting

Chemical parameters: Results in table (2) show contents of soluble solids contents (SSC), vitamin C and titrable acidity in pod at different maturity stages. It is obvious from such data that maturity of pods influences SSC, vitamin C and acidity. Soluble solids contents wasincreased gradually until $36 \mathrm{DAF}$ then decreased in pods during both seasons. Similar trend was obtained by Moneruzzamanet al. (2008) on tomato, and Sturm et al. (2003) and Ornelas-Paz et al.(2013) on strawberry. Similarly, soluble solids increased continuously during blackberry fruits development (Tosunet al., 2008). The obtained results may be due to the fact that the content of SSC is a function of several factors as total sugars, so this increase in SSC during maturity stage perhaps due to increase in total sugar (Sturm et al., 2003). The results show that vitamin $C$ was decreased continuously during pods development from 8 to 52 DAF in both seasons, although some changes were not statistically significant. Similarly, Lee et al. (1982) reported that large and more mature peas contained less ascorbic acid than smaller and immature peas. Also, Hoover (1952) onsouthern peas found that vitamin C was content decreased with maturity on a dry weight basis from $135 \mathrm{mg}$ per $100 \mathrm{~g}$ on the $10^{\text {th }}$ day after flowering to $15 \mathrm{mg}$ per $100 \mathrm{~g}$ on the $20^{\text {th }}$ day. This decrease in vitamin $\mathrm{C}$ may be due to biochemical oxidation (Vendramini and Trugo, 2000), and to the increase in growth of pods (Nagy, 1980).With regard to titrable acidity, as shown in table (2) acidity increased in pod until 40 DAF then decreased, in both seasons. Similar findings have also been observed in strawberry by Ornelas-Pazet al.(2013). 
J. Plant Production, Mansoura Univ., Vol. 5 (2), February, 2014

2

309 
EI-Seifi, S.K. et al. 
Data recorded in table (2) show the content of chlorophyll a, b and carotenoids in pods at different maturity stages. In general, the obtained data indicated that chlorophyll $\mathrm{a}, \mathrm{b}$ and carotenoids declined continuously during pod development stages with a sharp reduction from 8 to $16 \mathrm{DAF}$, and then a gradual decrease was noticed. there was no significant different between stages from 16 to $24^{\text {th }}$ day in both seasons for chlorophyll a and from 16 to $28^{\text {th }}$ day in the first season for chlorophyll $b$ and from 20 to $28^{\text {th }}$ day in the second season for chlorophyll b. Similar trend was found for ambarella by Ishaket al. (2005) who indicated that total chlorophyll content was 0.56 $\mathrm{mg} / 100 \mathrm{~g}$ in green fruits, $0.43 \mathrm{mg} / 100 \mathrm{~g}$ in half-ripe and $0.38 \mathrm{mg} / 100 \mathrm{~g}$ in ripe fruits. This decrease probably attributes to degradation of chlorophyll during pod development. During maturation process of the fruits, the chlorophyll content was decreased as a consequence of a process of biodegradation catalyzed by the chlorophyllase enzyme. In the first stage, the hydrolysis of the phytol takes place and in the second one, the porfirinic nucleus decomposes liberating magnesium (Fleancu, 2007).

Dry matter and fiber content in pod at different maturity stages are presented in Table (3). The results show that dry matter was increased continuously during pods development. These results are in harmony with those of Bisson and Jones (1932) on peas. The increase in the percentage dry matter after 44 DAF must have been due to the loss of water accompanying ripening. Regarding fiber, the results illustrated that crude fiber in pods continuously increased during maturity stages. This trend is similar to that reported before by Bisson and Jones (1932) on peasand Hoover (1952) on green beans. The fiber content of the side wall is the most important constituent which influences the edible quality of sugar snap peas. Fiber in pod was increased rapidly until 28 DAF and increased slowly till 52 DAF. The obtained results are also in agreement with Bisson and Jones (1932). The increase in fiber contents from 40 to 52 DAF in pod may be due to transferring carbohydrates to crude fiber in the pods. So, harvesting sugar snap peas at the $28^{\text {th }}$ day is the best maturity stage which has low fiber content, based on the condition of our experiment.

The results illustrated in table (3) present the content of sugars (total, reducing and non-reducing) in pods at different maturity stages. Total sugars and reducing sugars in pod increased until the $36^{\text {th }}$ day then decreased after in both seasons, while non-reducing sugars increased until the $40^{\text {th }}$ and the $28^{\text {th }}$ days in the first and second season, respectively, then decreased up to 48 DAF. At 52 DAF the highest non-reducing sugars was observed in both seasons. The gradual increase in sugars content found in this study is consistent with the result of Bisson and Jones (1932) on peas. The obtained results are also in agreement with the results of Montero et al. (1996) who found that the content of glucose and fructose in ripening 'Chandler' strawberry fruit was increased continuously during 35 days after fruit set and decreased after 42 days from fruit set, while sucrose content was increased continuously until 21 to 28 days after fruit set and then decreased gradually during the rest of the ripening process. The increase in total sugar content might be due to conversion of starch into sugars (Moneruzzamanet al., 2008). 
As shown in table (3), the highest phenolic content value was at the $8^{\text {th }}$ day in both seasons, and then decreased up to the $36^{\text {th }}$ and the $32^{\text {nd }}$ days in the first and second seasons, respectively. After that, total phenolic content again increased slightly until the $52^{\text {nd }}$ day in both seasons. Similar findings have been reported by Fawole and Opara (2013) who reported that total phenolic content was $2027 \mathrm{mg} / 100 \mathrm{ml}$ at the early immature stage, 550mg $1100 \mathrm{ml}$ at the half ripe stage and $583.72 \mathrm{mg} / 100 \mathrm{ml}$ at the full-ripe stage of pomegranate fruits. Ishaket al. (2005)also reported similar trend of results in ambarella fruits. The decline in phenolic contents probably attributes to the oxidation of phenolic compounds by polyphenol oxidase during fruits maturity (Amiotet al., 1995).

\section{CONCLUSION AND RECOMMENDATION}

The results of two experiments indicated that the best maturity stage to harvest sugar snap pea pods is 28 days after flowering because at that time the pods have high quality features such as low crude fiber, dry weight percentage as well as length and width of pods are proper for consumers and SSC, vitamin C, sugars and phenolic are still high.

\section{REFERENCES}

A.O.A.C. (1996). Official methods of analysis, association of official analytical chemists, Washington DC.

Amiot, M.J., M. Tacchini, S.Y. Aubert and W. Oleszek (1995). Influence of cultivar, maturity stage, and storage conditions on phenolic composition and enzymatic browning of pear fruits. Journal of Agricultural and Food Chemistry 43(5): 1132-1137.

Basterrechea, M. and J.R. Hicks (1991). Effect of maturity on carbohydrate changes in sugar snap pea pods during storage.ScientiaHorticulturae 48: $1-4$

Bisson, C.S. and H.A. Jones (1932). Changes accompanying fruit development in the garden pea. Plant Physiology 7: 91-106.

Dubois, M.K.A., J.K. Hamilton, P.A. Rebers and F. Smith (1956).Colorimetric method for determination of sugars and related substances, Anal. Chem. 28: 350-356.

Fawole, O.A. and U.L. Opara (2013). Effects of maturity status on biochemical content, polyphenol composition and antioxidant capacity of pomegranate fruit arils (cv. 'Bhagwa'). South African Journal of Botany 85: 23-31.

Fleancu, M. (2007).Correlations among some physiological processes in apple fruit during growing and maturation processes. International Journal of Agriculture and Biology 9 (4):613 - 616.

Hocking, D.F. (1997). Snow peas and sugar snap peas. Agfact H8.1.35, NSW Agric., Sydney, Australia. 
Hoover, M.W. (1952). The importance of stage of maturity upon the edible quality of green beans, lima beans and southern peas.FloridaState Horticultural Society Vol. LXV: 133-137.

Ishak, S.A., N. Ismail, M.A.M. Noor and H. Ahmad (2005). Some physical and chemical properties of ambarella (SpondiascythereaSonn.) at three different stages of maturity. Journal of Food Composition and Analysis 18: 819-827.

Lee, C.Y., L.M. Jr. Massey and J.P. Van Buren (1982). Effects of ostharvest handling and processing on vitamin contents of peas. Journal of food science 47: 961-964.

Lichenthaler, H.K. and W.R. Wellburn (1983). Determination of total carotenoids and chlorophylls $a$ and $b$ of leaf extracts in different solvents. Biochem. Soc. Trans. 11: 591-592.

Maynard, A.J. (Ed.) (1970). Methods in Food Analysis, Academic Press, New York, p. 176.

Mazumdar, B.C. and K. Majumder(2003).Methods on physico-chemical analysis of fruits.Daya Publishing House, Delhi-110035, pp.162-163.

Moneruzzaman, K.M., A.B.M.S. Hossain, W. Sani and M. Saifuddin(2008). Effect of stages of maturity and ripening conditions on the biochemical characteristics of tomato. American Journal of Biochemistry and Biotechnology 4 (4): 336-344.

Montero, T. M., E. M. Molla, R. M. Esteban and F. J. Lopez-Andreu (1996). Quality attributes of strawberry during ripening. ScientiaHorticulturae. 65: 239-250.

Moore, T.C. (1974). Research experiences in plant physiology. A laboratoryManual. Springer-Verlage, Berlin, Heidelberg, p. 3-12.

Nagy, S. (1980). Vitamin C contents of citrus fruit and their products: a review. J. Agric. Food Chem. 28: 8-18.

Ornelas-Paz, J. De J., E.M. Yahia, N. Ramirez-Bustamante, J.D. PerezMartinez, M.d. P. Escalante-Minakata, V. Ibarra-Junquera, C. AcostaMuniz, V. Guerrero-Prieto and E. Ochoa-Reyes (2013). Physical attributes and chemical composition of organic strawberry fruit (Fragaria $x$ ananassaDuch, Cv. Albion) at six stages of ripening. Food Chemistry 138: 372-381.

Pearson, D. (1970). The chemical analysis of foods (6th ed.), T.A Constable, London.

Sturm, K., D. Koron and F. Stampar (2003). The composition of fruit of different strawberry varieties depending on maturity stage. Food Chemistry 83: 417-422.

Tosun, I., N.S. Ustun and B. Tekguler (2008).Physical and chemical changes during ripening of blackberry fruits. Sci. Agric. 65(1): 87-90.

Vendramini, A.L. and L.C. Trugo (2000). Chemical composition of acerola fruit (Malpighiapunicifolia L.) at three stages of maturity. Food Chemistry 71 : 195-198.

Watadal, A.E. and L.L. Morris (1967).Growth and respiration patterns of snap bean fruits. Plant Physiology 42:757-761. 
تأثير مرحلة النضج على الخصائص الفيزيائيسة و الكيميائيسة و تحديد موعد الحصـاد

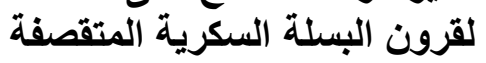

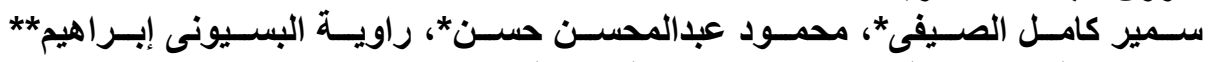

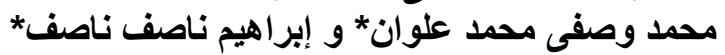

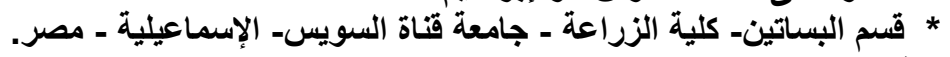

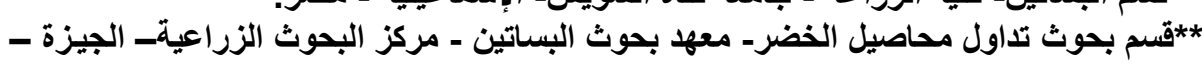

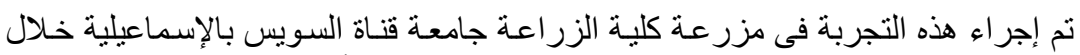

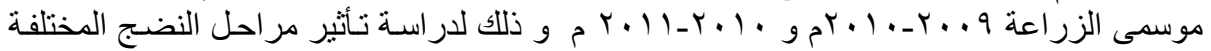

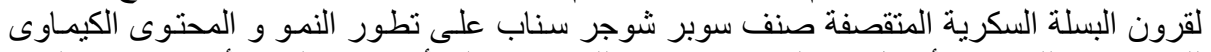

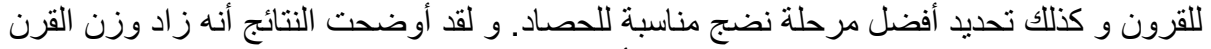

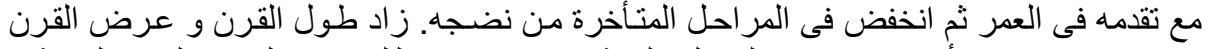

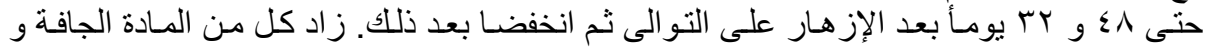

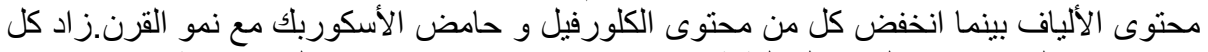

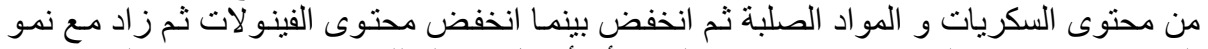

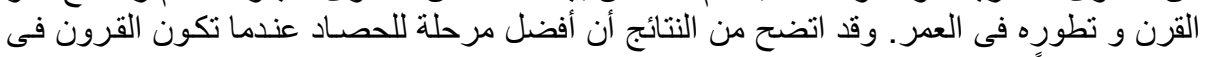
عمر ب ب يوماً بعد الإزهار.

كلية الزراعة - جامعة المنصورة

قام بتحكيم البحث مركز البحوث الزراعية

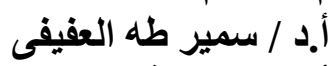

أ.د / عبد اللة حلمى على طلى العفي 
J. Plant Production, Mansoura Univ., Vol. 5 (2), February, 2014 
Table (2): Content of SSC, vitamin C, acidity, chlorophyll a, b and carotenoids in pod at different maturity stages during 2009-2010 and 2010-2011 seasons.

\begin{tabular}{|c|c|c|c|c|c|c|c|c|c|c|c|c|}
\hline \multirow{2}{*}{$\begin{array}{l}\mathrm{H}^{*} \text {. Date } \\
\text { (days) }\end{array}$} & \multicolumn{6}{|c|}{ 2009-2010 } & \multicolumn{6}{|c|}{$2010-2011$} \\
\hline & $\begin{array}{l}\text { SSC } \\
\text { Brix }^{\circ}\end{array}$ & $\begin{array}{c}\text { Vitamin } \\
\text { C } \\
(\mathrm{mg} / 100 \\
\mathrm{g} \mathrm{FW})\end{array}$ & $\begin{array}{c}\text { Acidity } \\
\%\end{array}$ & $\begin{array}{c}\text { Chlo. a } \\
\text { (mg/100 } \\
\text { g FW) }\end{array}$ & $\begin{array}{c}\text { Chlor. b } \\
\text { (mg/100 } \\
\text { g FW) }\end{array}$ & $\begin{array}{c}\text { Carot. } \\
\text { (mg/100 } \\
\text { g FW) }\end{array}$ & $\begin{array}{l}\text { SSC } \\
\text { Brix }\end{array}$ & $\begin{array}{c}\text { Vitamin } \\
\text { C } \\
(\mathrm{mg} / 100 \\
\mathrm{g} \mathrm{FW})\end{array}$ & $\begin{array}{c}\text { Acidity } \\
\%\end{array}$ & $\begin{array}{c}\text { Chlo. a } \\
\text { (mg/100 } \\
\text { g FW) }\end{array}$ & $\begin{array}{c}\text { Chlor. b } \\
\text { (mg/100 } \\
\text { g FW) }\end{array}$ & $\begin{array}{c}\text { Carot. } \\
\text { (mg/100 } \\
\text { g FW) }\end{array}$ \\
\hline 8 & $7.50 \mathrm{fg}$ & $117.30 \mathrm{a}$ & $2.62 \mathrm{f}$ & $17.28 \mathrm{a}$ & $8.04 \mathrm{a}$ & $18.74 \mathrm{a}$ & $8.33 \mathrm{~g}$ & $167.22 \mathrm{a}$ & $2.57 \mathrm{~g}$ & $13.92 \mathrm{a}$ & $8.79 \mathrm{a}$ & $18.67 \mathrm{a}$ \\
\hline 12 & $7.17 \mathrm{~g}$ & $131.01 \mathrm{a}$ & $2.63 \mathrm{f}$ & $11.27 \mathrm{~b}$ & $5.49 \mathrm{~b}$ & $11.18 \mathrm{~b}$ & $8.33 \mathrm{~g}$ & $131.79 \mathrm{~b}$ & $2.67 \mathrm{fg}$ & $10.87 \mathrm{~b}$ & $7.55 \mathrm{~b}$ & $15.44 \mathrm{~b}$ \\
\hline 16 & $7.17 \mathrm{~g}$ & $84.50 \mathrm{~b}$ & $2.76 \mathrm{f}$ & $6.58 c$ & $3.66 \mathrm{c}$ & $10.99 \mathrm{bc}$ & $8.67 \mathrm{~g}$ & $89.81 \mathrm{c}$ & $2.75 \mathrm{e}-\mathrm{g}$ & $6.79 \mathrm{c}$ & $3.91 \mathrm{c}$ & $11.35 \mathrm{c}$ \\
\hline 28 & $9.50 \mathrm{~d}$ & 61.39 b-e & $4.55 \mathrm{a}-\mathrm{c}$ & $5.15 \mathrm{~d}$ & $2.49 \mathrm{c}-\mathrm{f}$ & 8.37 ef & $11.00 \mathrm{~d}$ & $59.77 \mathrm{f}$ & $3.32 \mathrm{~cd}$ & $5.29 \mathrm{~d}$ & $2.66 \mathrm{~d}-f$ & $8.61 \mathrm{e}$ \\
\hline 32 & $11.00 \mathrm{c}$ & $55.20 \mathrm{c}-\mathrm{e}$ & $4.65 \mathrm{a}-\mathrm{c}$ & $4.59 \mathrm{de}$ & $2.16 \mathrm{~d}-\mathrm{f}$ & $7.38 \mathrm{f}$ & $12.47 \mathrm{c}$ & $56.50 \mathrm{f}$ & $3.40 \mathrm{~cd}$ & $4.72 \mathrm{de}$ & $2.31 \mathrm{e}-\mathrm{g}$ & $7.58 \mathrm{f}$ \\
\hline 36 & $12.27 \mathrm{a}$ & $52.91 \mathrm{c}-\mathrm{e}$ & $4.85 \mathrm{ab}$ & 4.03 ef & $1.88 \mathrm{~d}-\mathrm{f}$ & $6.30 \mathrm{~g}$ & $13.77 \mathrm{a}$ & $55.36 \mathrm{f}$ & $3.53 \mathrm{bc}$ & 4.16 ef & $2.04 \mathrm{f}-\mathrm{h}$ & $6.51 \mathrm{~g}$ \\
\hline 40 & $12.17 \mathrm{a}$ & $49.73 \mathrm{c}-\mathrm{e}$ & $5.05 \mathrm{a}$ & 3.79 ef & 1.43 ef & $6.07 \mathrm{~g}$ & $13.70 \mathrm{a}$ & $50.51 \mathrm{~g}$ & $4.32 \mathrm{a}$ & $3.97 \mathrm{f}$ & $1.65 \mathrm{gh}$ & $6.36 \mathrm{~g}$ \\
\hline 44 & $\begin{array}{c}11.97 \\
a b\end{array}$ & 47.17 c-e & 3.9 & 3.82 ef & 1.5 & $5.78 \mathrm{gh}$ & $\begin{array}{c}13.47 \\
a b\end{array}$ & $48.51 \mathrm{~g}$ & $4.08 \mathrm{ab}$ & $3.93 \mathrm{f}$ & $1.64 \mathrm{gh}$ & $5.96 \mathrm{gh}$ \\
\hline 48 & $\begin{array}{c}11.50 \\
b c\end{array}$ & $46.45 \mathrm{de}$ & $3.33 \mathrm{e}$ & $3.60 \mathrm{f}$ & 1.47 ef & $4.86 \mathrm{hi}$ & $\begin{array}{c}13.00 \\
b c\end{array}$ & $45.95 \mathrm{~g}$ & 3.30 c-e & $3.71 \mathrm{f}$ & $1.61 \mathrm{gh}$ & $5.03 \mathrm{hi}$ \\
\hline
\end{tabular}


Table (3):Content of dry weight, fiber,sugars (total, reducing and non-reducing) and total phenolic in pod at different maturity stages during 2009-2010 and 2010-2011seasons.

\begin{tabular}{|c|c|c|c|c|c|c|c|c|c|c|c|c|}
\hline \multirow{3}{*}{$\begin{array}{l}\mathrm{H}^{\star} . \\
\text { (days) }\end{array}$} & \multicolumn{6}{|l|}{$2009-2010$} & \multicolumn{6}{|c|}{ 2010-2011 } \\
\hline & \multirow{2}{*}{$\begin{array}{c}\text { Dry } \\
\text { weight \% }\end{array}$} & \multirow{2}{*}{$\begin{array}{c}\text { Fiber } \\
\%\end{array}$} & \multicolumn{3}{|c|}{ Sugars (mg/g FW) } & \multirow{2}{*}{$\begin{array}{c}\text { Phenols } \\
\text { (mg/100 } \\
\text { g FW) }\end{array}$} & \multirow{2}{*}{$\begin{array}{c}\text { Dry } \\
\text { weight } \\
\%\end{array}$} & \multirow{2}{*}{$\begin{array}{c}\text { Fiber } \\
\%\end{array}$} & \multicolumn{3}{|c|}{ Sugars (mg/g FW) } & \multirow{2}{*}{$\begin{array}{c}\text { Phenols } \\
\text { (mg/100 g } \\
\text { FW) }\end{array}$} \\
\hline & & & Red. & $\begin{array}{l}\text { Non- } \\
\text { red. }\end{array}$ & Total & & & & Red. & $\begin{array}{l}\text { Non- } \\
\text { red. }\end{array}$ & Total & \\
\hline 8 & $9.22 \mathrm{e}$ & $4.02 \mathrm{~g}$ & $6.15 \mathrm{~g}$ & $10.61 \mathrm{~g}$ & $17.31 \mathrm{~g}$ & $60.77 \mathrm{a}$ & $8.56 \mathrm{~d}-\mathrm{f}$ & $4.31 \mathrm{~g}$ & $6.37 i$ & $9.38 \mathrm{~g}$ & $16.24 \mathrm{i}$ & $55.37 \mathrm{a}$ \\
\hline 12 & $9.54 \mathrm{c}-\mathrm{e}$ & $6.41 \mathrm{f}$ & $15.09 f$ & $12.64 \mathrm{fg}$ & $28.39 f$ & $34.32 \mathrm{~b}$ & $8.04 f$ & $6.58 \mathrm{f}$ & $15.30 \mathrm{~h}$ & $11.91 \mathrm{fg}$ & $27.84 \mathrm{~h}$ & $30.42 \mathrm{~b}$ \\
\hline 16 & $9.26 \mathrm{e}$ & $7.64 \mathrm{e}$ & $17.43 \mathrm{f}$ & $13.27 \mathrm{fg}$ & $31.40 \mathrm{f}$ & 28.27 bc & 8.41 ef & $7.87 \mathrm{e}$ & $20.73 \mathrm{fg}$ & $14.69 f$ & $36.19 \mathrm{~g}$ & $27.65 \mathrm{bc}$ \\
\hline 20 & $9.42 \mathrm{de}$ & $7.81 \mathrm{e}$ & $25.17 \mathrm{e}$ & $15.72 f$ & $41.71 \mathrm{e}$ & $26.32 \mathrm{~cd}$ & $9.03 \mathrm{c}-\mathrm{e}$ & $8.28 \mathrm{e}$ & 25.62 ef & 28.94 e & $56.08 f$ & $25.26 \mathrm{~cd}$ \\
\hline 24 & $9.73 \mathrm{c}-\mathrm{e}$ & $9.51 \mathrm{~d}$ & $30.93 d$ & $30.04 \mathrm{e}$ & $62.54 \mathrm{~d}$ & $20.68 \mathrm{de}$ & $9.19 \mathrm{c}-\mathrm{e}$ & $9.95 \mathrm{~d}$ & $30.92 \mathrm{~cd}$ & $39.55 \mathrm{~cd}$ & $72.54 \mathrm{de}$ & 20.42 ef \\
\hline 28 & 10.07 b-e & $10.82 \mathrm{c}$ & $35.56 \mathrm{c}$ & $29.68 \mathrm{e}$ & $66.80 \mathrm{~cd}$ & $19.52 \mathrm{de}$ & $9.40 \mathrm{~b}-\mathrm{d}$ & $11.19 \mathrm{c}$ & $35.18 \mathrm{bc}$ & $44.40 \mathrm{~b}$ & 81.91 bc & $16.46 \mathrm{~g}$ \\
\hline 32 & 10.38 a-e & $11.89 \mathrm{~b}$ & $39.75 \mathrm{~b}$ & $36.98 d$ & $78.68 \mathrm{~b}$ & $17.39 \mathrm{e}$ & $9.61 \mathrm{bc}$ & $12.18 \mathrm{bc}$ & $40.31 \mathrm{ab}$ & $43.38 \mathrm{~b}$ & $85.98 a b$ & $16.41 \mathrm{~g}$ \\
\hline 36 & 10.65 a-d & $11.87 \mathrm{~b}$ & $46.68 \mathrm{a}$ & $42.04 \mathrm{c}$ & $90.93 \mathrm{a}$ & $17.14 \mathrm{e}$ & 9.82 bc & $12.27 \mathrm{~b}$ & $44.99 \mathrm{a}$ & $42.47 \mathrm{bc}$ & 89.70 a & $16.82 \mathrm{~g}$ \\
\hline 40 & 10.76 a-c & $12.04 \mathrm{~b}$ & $37.87 \mathrm{bc}$ & $48.44 \mathrm{a}$ & 88.86 a & $17.90 \mathrm{e}$ & 9.78 bc & $12.51 \mathrm{~b}$ & $44.80 \mathrm{a}$ & $42.61 \mathrm{bc}$ & $89.65 \mathrm{a}$ & $18.21 \mathrm{fg}$ \\
\hline 44 & $11.25 a b$ & $12.50 \mathrm{~b}$ & $29.05 d$ & $46.66 \mathrm{ab}$ & $78.17 b$ & $18.19 \mathrm{e}$ & $10.22 b$ & $12.42 b$ & $36.88 \mathrm{~b}$ & $39.65 \mathrm{~cd}$ & $78.62 \mathrm{~cd}$ & $18.56 \mathrm{fg}$ \\
\hline 48 & $11.62 \mathrm{a}$ & $12.37 b$ & $22.54 \mathrm{e}$ & $44.56 \mathrm{bc}$ & $69.43 \mathrm{c}$ & 20.49 de & $11.53 \mathrm{a}$ & $13.07 \mathrm{~b}$ & $29.42 \mathrm{de}$ & $39.00 \mathrm{~d}$ & 70.47 e & $18.66 \mathrm{fg}$ \\
\hline 52 & $11.63 \mathrm{a}$ & $13.58 \mathrm{a}$ & $14.76 \mathrm{f}$ & $49.46 \mathrm{a}$ & $66.83 \mathrm{~cd}$ & $22.29 \mathrm{c}-\mathrm{e}$ & $11.90 \mathrm{a}$ & $14.24 \mathrm{a}$ & $17.50 \mathrm{gh}$ & $47.74 \mathrm{a}$ & $67.75 \mathrm{e}$ & $23.10 \mathrm{de}$ \\
\hline
\end{tabular}

Values are the means of 3 replicates each with 7 pods. Values followed by the same letter within a column are not significantly different at the $0.05 \%$ level of probability according to LSD test.

$\mathbf{H}^{\star}=$ Harvesting 